\title{
Effects of nutrient intake and number of oestrous cycles on in vitro development of preimplantation pig embryos
}

\author{
J. R. Graham, L. J. Ray, S. K. Stover, J. J. Salmen and C. S. Gardiner* \\ Department of Biology, University of Northern Colorado, Greeley, CO 80639, USA
}

\begin{abstract}
The effects of nutrient intake and insemination of gilts at first versus third oestrus on the in vitro development of preimplantation pig embryos were investigated. Standard swine management involves ad libitum feeding of gilts at first oestrus and restricted feeding of gilts at third oestrus. According to previous research, gilts inseminated at first oestrus demonstrate greater embryonic mortality than gilts inseminated at third oestrus, and it is possible that differences in nutrient intake between gilts inseminated at first versus third oestrus affect the viability of eggs or embryos. In the present study, experimental gilts were assigned to three treatments: animals designated 1A were inseminated at first oestrus and fed ad libitum; animals designated 3R were inseminated at third oestrus and were fed a restricted diet; and $3 \mathrm{~A}$ animals were inseminated at third oestrus and fed ad libitum. Embryos collected from each treatment group were cultured in vitro, and data were evaluated according to cell stage at collection. Comparison of treatments $1 \mathrm{~A}$ and $3 \mathrm{R}$ supported the contention of increased embryo mortality in gilts inseminated at first oestrus under normal management conditions. When cultures were initiated at the one- to two-cell or two- to four-cell stages, the percentage of $1 \mathrm{~A}$ embryos developing to the morula stage $(50.9 \%, 68.0 \%)$ was significantly lower than that of $3 \mathrm{R}$ embryos $(88.9 \%, 90.9 \% ; P<0.05)$. Comparison of treatments $1 \mathrm{~A}$ and $3 \mathrm{~A}$ addressed effects due to the number of oestrous cycles. Significantly more two- to four-cell embryos from gilts inseminated at third oestrus and fed ad libitum reached the morula and expanded blastocyst stages of development $(87.0 \%, 41.3 \%)$ compared with embryos from gilts inseminated at first oestrus and fed ad libitum $(68.0 \%, 20.3 \% ; P<0.05)$. Finally, the effects of ad libitum feeding were determined by comparing treatments $3 \mathrm{~A}$ and $3 \mathrm{R}$. These data were inconclusive, as both positive and negative effects were observed. More one- to two-cell embryos from treatment $3 \mathrm{R}$ developed to the morula stage $(88.9 \%)$ compared with $3 \mathrm{~A}$ embryos collected at the same stage $(64.7 \%)$, whereas a greater number of $3 \mathrm{~A}$ embryos in the two- to four-cell category reached the expanded blastocyst stage $(41.3 \%)$ than $3 \mathrm{R}$ embryos $(21.2 \% ; P<0.05)$. These results support the hypothesis of lower in vitro developmental capacity for embryos collected from gilts inseminated at first oestrus. Furthermore, the findings indicate that differences in embryo viability between gilts inseminated at first versus third oestrus are related to the number of oestrous cycles and possibly to differential nutrition.
\end{abstract}

\section{Introduction}

Prenatal mortality accounts for a $35-45 \%$ loss of offspring in swine, and the largest percentage loss occurs during early embryonic development (Pope and First, 1985). Gilts mated at first oestrus show lower ovulation rates (Robertson et al., 1951; Anderson and Einarsson, 1980; Paterson and Lindsay, 1980; Archibong et al., 1987) and greater embryonic mortality (Warnick et al., 1951; MacPherson et al., 1977; Young and King, 1981; Archibong et al., 1987) than gilts inseminated at a later oestrus. Furthermore, embryos collected from gilts

*Correspondence.

Received 21 September 1998. inseminated at first oestrus show reduced in vitro development compared with embryos collected from the same gilts at third oestrus (Menino et al., 1989). There is some evidence that uteri from gilts at first oestrus are less developed than those from gilts at third oestrus (Murray and Grifo, 1976). However, the increased mortality of embryos from gilts inseminated at first oestrus does not appear to be due to an unfavourable intrauterine environment, as demonstrated by equivalent survival rates of embryos transferred from gilts inseminated at second oestrus to oviducts of recipients at either first or third oestrus (Archibong et al., 1992). Although fertilization rates of gilts inseminated at first oestrus are similar to those of gilts inseminated at third oestrus (Young and King, 1981; 
Archibong et al., 1987), it has been suggested that ova released by gilts at first oestrus are inferior in quality (Archibong ef al., 1992; Koenig and Stormshak, 1993).

Gilts at first oestrus differ from those at third oestrus both in terms of follicular steroid production and preovulatory follicle size. Gilts at first oestrus show lower concentrations of certain follicular steroids (testosterone, oestradiol, androstenedione) and a greater number of small follicles (4-8 $\mathrm{mm}$ in diameter) than gilts at a later oestrus (Smith et al., 1992). Whether the differences in follicular steroid concentration lead to production of oocytes or embryos of decreased viability is unclear. However, it has been demonstrated that plasma steroid concentrations can affect embryo survival (Anderson, 1978; Pope and First, 1985; Dziuk, 1987; Blair et al., 1994). Blair et al. (1994) reported that increased embryonic survival and decreased embryonic diversity in pigs may be associated with a closer synchrony between the onset of oestrus, the peak in oestradiol concentration and the LH surge. Furthermore, embryonic development is asynchronous within pig and sheep litters (Anderson, 1978; Wilmut and Sales, 1981), and some embryonic death may be due to secretion of oestrogens by more advanced conceptuses (Pope and First, 1985; Dziuk, 1987). However, the relationship between embryo loss in gilts inseminated at first oestrus and intra-litter asynchrony remains unclear.

The effect of energy intake on ovulation rate is well documented and has led to the practice of flushing livestock to increase ovulation rate (Hartog and van Kempen, 1980). However, nutritional flushing (Emerson and Hendricks, 1977) and high energy intake during rearing (Hartog and van Kempen, 1980; Kirkwood and Thacker, 1988; Whaley et al., 1997) increases embryonic mortality in gilts, whereas restricting feed intake during early gestation can lead to increased embryonic survival in vivo (Robertson et al., 1951) and increased fetal weight (Bryan and Hagen, 1991). Injecting well-fed gilts ( $2 \times$ maintenance feed per day) with progesterone after the onset of oestrus also appears to increase embryonic survival, indicating that periovulatory plasma progesterone concentration is involved in mediating nutrition-induced effects on embryos (Jindal et al., 1997). Furthermore, Zak et al. (1997) found fewer large follicles (>7 mm in diameter) and fewer oocytes at metaphase II in lactating feed-restricted sows, indicating that the size of pig preovulatory follicles and the maturation rate of oocytes obtained from preovulatory follicles can be influenced by feed intake during lactation. Finally, leptin, a regulatory protein associated with follicular development (Barash et al., 1996) and polarization of the preimplantation embryo (Antczak and Van Blerkom, 1997), may also be involved in regulating food intake, as mice lacking endogenous leptin showed significant decreases in food intake and body weight after receiving leptin injections (Weigle et al., 1995).

Swine management systems frequently allow ad libitum feeding of gilts at first oestrus, whereas gilts at a later oestrus receive a limited diet. This difference in nutrient intake may affect the production of viable eggs or embryos and may account, at least in part, for the difference in embryonic mortality rates between gilts inseminated at first versus third oestrus.

The objective of this study was to investigate the effects of nutrition and insemination at first versus third oestrus on in vitro development of preimplantation pig embryos. Studying the effects of excess nutrients on embryo viability may increase understanding of the origins and mechanisms of embryonic mortality.

\section{Materials and Methods}

\section{Animals}

Forty-five crossbred gilts from 12 litters were represented in the study. Full siblings were distributed across treatment groups, housed in confinement at the Southern Illinois University Swine Center, and maintained under identical conditions until display of first oestrus. Gilts were penned adjacent to boars, checked twice a day for behavioural oestrus, beginning at approximately 130 days of age, and fed a $14 \%$ crude protein diet ad libitum. Gilts assigned to the first treatment (1A) were inseminated at their first oestrus and fed ad libitum. In the second treatment (3R), gilts were restricted to $1.82 \mathrm{~kg}$ of a $14 \%$ crude protein diet per day after their first oestrus and were inseminated at third oestrus. Gilts in the third treatment $(3 \mathrm{~A})$ were fed ad libitum throughout the experimental period and were inseminated at third oestrus. Pre-pubertal gilts on restricted diets tend to come into oestrus at different ages, if at all. Therefore, a restricted diet treatment group was not included at first oestrus.

\section{Embryo recovery}

Gilts were artificially inseminated with fresh semen pooled from two boars at 0 and $12 \mathrm{~h}$ after detection of oestrus. At $36-48 \mathrm{~h}$ after detection of oestrus, gilts were anaesthetized with a combination of $10 \mathrm{ml}$ acepromazine and $40 \mathrm{ml}$ ketamine i.m., and their reproductive tracts were exposed. The local anaesthetic, lidocaine $(25 \mathrm{ml})$, was also applied along the incision area. Ovaries were inspected to confirm the gilts were at first oestrus, and the number of ovulations was recorded. Embryos were collected by flushing the oviducts and uteri with Whitten's medium (Whitten and Biggers, 1968) buffered with Hepes and without BSA. Each gilt was flushed only once. All embryos were collected within $12 \mathrm{~h}$ starting at $36 \mathrm{~h}$ after oestrus was detected. The embryos collected were cultured in vitro and observed once a day for 8 days under an inverted stage phase-contrast microscope at $\times 200$ to determine developmental potential. Indication of fertilization, stage of development, quality of embryos, and abnormal features were recorded. Embryos were cultured in microdrops of Whitten's medium with $15 \mathrm{mg} \mathrm{BSA} \mathrm{ml}{ }^{-1}$ under paraffin oil in a humidified atmosphere of $5 \% \mathrm{CO}_{2}$ in air at $37^{\circ} \mathrm{C}$. Three to six embryos were cultured in each $30-40 \mu \mathrm{l}$ drop.

\section{Statistical analysis}

Differences in the number of ovulations and ova recovered were evaluated using analysis of variance and least significant 
Table 1. Reproductive characteristics of gilts

\begin{tabular}{lccc}
\hline & \multicolumn{3}{c}{ Treatment } \\
\cline { 2 - 4 } & $1 \mathrm{~A}$ & $3 \mathrm{R}$ & $3 \mathrm{~A}$ \\
\hline Number of gilts & 15 & 12 & 11 \\
Number of ovulations $^{\mathrm{a}}$ & $12.6 \pm 0.7$ & $14.0 \pm 0.3$ & $15.2 \pm 0.7$ \\
Number of embryos $^{\mathrm{a}}$ & $9.4 \pm 0.8$ & $10.8 \pm 0.6$ & $12.0 \pm 1.0$ \\
Percentage embryo recovery & 74.0 & 77.4 & 79.0 \\
\hline
\end{tabular}

aMean \pm SEM

$1 \mathrm{~A}$, animals were inseminated at first oestrus and fed ad libitum; $3 \mathrm{R}$, animals were inseminated at third oestrus and fed a restricted diet; $3 \mathrm{~A}$, animals were inseminated at third oestrus and fed ad libitum.

difference procedures. Differences in recovery rate, percentage of embryos at each developmental stage at time of collection, and degree of in vitro development were evaluated using chi-squared analysis (Steel and Torrie, 1980; Hinkle et al., 1988).

\section{Results}

\section{Distribution of cell stages}

Embryos were collected from a total of 38 gilts. Seven of the original 45 gilts in the study were eliminated for various reasons unrelated to the experiment. The number of ovulations and number of embryos recovered did not differ among the three treatments $(P<0.05$; Table 1$)$. The number of embryos collected at each stage of development is summarized (Table 2). A total of 14 embryos that were collected were not used in the developmental study for reasons unrelated to the experiment (for example, embryo loss, contamination during transfer). Because embryos collected at later stages are more likely to develop to the morula and blastocyst stages in culture, development was analysed according to developmental stage at collection. The one- to eight-cell category was established for individual flushes that contained embryos at three or more cell stages. The percentage of embryos collected at different cell stages varied considerably among the three treatments $(P<0.05$; Fig. 1). Although more one- to two-cell embryos were recovered from the $1 \mathrm{~A}$ and $3 \mathrm{R}$ treatment groups than from the $3 \mathrm{~A}$ group, the number of embryos in the one- to eight-cell category was higher for treatments $3 \mathrm{R}$ and $3 \mathrm{~A}$ than it was for treatment $1 \mathrm{~A}$.

\section{Embryonic development}

Considering embryo development without regard to initial cell stage, the only difference in development was that $3 \mathrm{~A}$ animals had a higher percentage of embryos developing to the compacted morula stage compared with $1 \mathrm{~A}$ and $3 \mathrm{R}$ animals (Table 2; $P<0.05$ ).

The percentage of embryos in each treatment developing to the morula stage is summarized (Fig. 2). When culture was initiated at the one- to two-cell stage, a larger percentage of $3 \mathrm{R}$ embryos developed to the morula stage $(88.9 \%)$ compared with $1 \mathrm{~A}(50.9 \%)$ or $3 \mathrm{~A}$ embryos $(64.7 \%)$. When culture was initiated at the two- to four-cell stage, $3 \mathrm{R}$ and $3 \mathrm{~A}$ embryos had a higher percentage of morula formation $(90.9 \%$ and $87.0 \%$, respectively) than did $1 \mathrm{~A}$ embryos $(68.0 \%)$. No difference was detected in morula formation in cultures initiated at the four- to eight-cell stage, whereas morula formation in the one- to eight-cell stage group was greater in treatment $3 \mathrm{~A}$ than in treatment $3 \mathrm{R}$.

No significant difference was observed in the percentage of blastocyst formation in the three treatments according to initial cell stage (Fig. 3). However, when culture was initiated at the two- to four-cell stage, a higher percentage of embryos from the $3 \mathrm{~A}$ animals reached the expanded blastocyst stage $(41.3 \%)$ than those from animals in treatments $1 \mathrm{~A}(20.3 \%)$ or 3R (21.2\%) (Fig. 4).

\section{Discussion}

Standard swine management often involves ad libitum feeding of gilts at first oestrus and restricted feeding of gilts at third oestrus. In agreement with other studies (Young and King, 1981; Archibong et al., 1987), the present study indicates increased embryo mortality in gilts inseminated at first oestrus under these standard conditions. When cultures were initiated at the one- to two-cell or two- to four-cell stages, morula formation by embryos from gilts inseminated at first oestrus and fed ad libitum was significantly lower compared with same stage embryos from gilts inseminated at third oestrus and fed a restricted diet.

Menino et al. (1989) demonstrated that fewer three- to eight-cell embryos from gilts inseminated at first oestrus reached the blastocyst and expanded blastocyst stages of development compared with gilts in third oestrus. In this study, a similar oestrus-related effect was observed on development to the morula stage, but not to the blastocyst or expanded blastocyst stage of development. This discrepancy may be explained by differences between the two studies. First, Menino et al. (1989) collected embryos from the same gilts at their first and third oestrus, whereas in the present study, a different group of gilts was used for each of the three treatments. Furthermore, in the present study, development to the compacted morula stage was used as the endpoint for the morula category, whereas Menino et al. (1989) may have included morulae that had not yet compacted.

Although it is possible that the hormonal environment associated with first oestrus in pigs is inherently defective and subsequently leads to the production of defective oocytes or embryos, differences in nutrition of gilts in first oestrus may also be responsible for differential embryonic mortality.

A detrimental effect of ad libitum feeding might explain, at least in part, the difference in embryonic development between gilts inseminated at first versus third oestrus observed in other studies (Young and King, 1981; Archibong et al., 1987), as normal swine management involves ad libitum feeding of gilts at first oestrus and keeping gilts at third oestrus on a restricted diet. Gilts at first oestrus frequently consume $50 \%$ more protein than gilts at second or later oestrus. Such high amounts of protein may adversely affect 
Table 2. Number of pig embryos collected at each stage and cultured in vitro

\begin{tabular}{|c|c|c|c|}
\hline & \multicolumn{3}{|c|}{ Treatment } \\
\hline & $1 \mathrm{~A}$ & $3 R$ & $3 \mathrm{~A}$ \\
\hline \multicolumn{4}{|l|}{ Total flushes used for culture experiments } \\
\hline Number of flushes & 14 & 12 & 11 \\
\hline Number of embryos cultured & 139 & 126 & 124 \\
\hline Percentage developed to morula & 61.9 & 75.4 & 78.2 \\
\hline Percentage developed to blastocyst & 45.3 & 44.4 & 51.6 \\
\hline Percentage developed to expanded blastocyst & 31.3 & 21.9 & 46.9 \\
\hline \multicolumn{4}{|l|}{ Flushes with one- to two-cell embryos } \\
\hline Number of embryos cultured & 57 & 54 & 17 \\
\hline Number developed to morula & 29 & 48 & 11 \\
\hline Number developed to blastocyst & 21 & 25 & 4 \\
\hline Number developed to expanded blastocyst & 2 & 2 & 2 \\
\hline \multicolumn{4}{|l|}{ Flushes with two- to four-cell embryos } \\
\hline Number of embryos cultured & 59 & 33 & 46 \\
\hline Number developed to morula & 40 & 30 & 40 \\
\hline Number developed to blastocyst & 32 & 17 & 32 \\
\hline Number developed to expanded blastocyst & 12 & 7 & 19 \\
\hline \multicolumn{4}{|l|}{ Flushes with four- to eight-cell embryos } \\
\hline Number of embryos cultured & 23 & 15 & 32 \\
\hline Number developed to morula & 17 & 14 & 27 \\
\hline Number developed to blastocyst & 10 & 12 & 20 \\
\hline Number developed to expanded blastocyst & 6 & 5 & 7 \\
\hline \multicolumn{4}{|l|}{ Flushes with one- to eight-cell embryos } \\
\hline Number of embryos cultured & 0 & 24 & 29 \\
\hline Number developed to morula & 0 & 3 & 19 \\
\hline Number developed to blastocyst & 0 & 2 & 8 \\
\hline Number developed to expanded blastocyst & 0 & 0 & 2 \\
\hline
\end{tabular}

$1 \mathrm{~A}$, animals were inseminated at first oestrus and fed ad libitum; $3 \mathrm{R}$, animals were inseminated at third oestrus and fed a restricted diet; $3 \mathrm{~A}$, animals were inseminated at third oestrus and fed ad libitum.

egg or embryo viability of gilts at first oestrus, as has been suggested for dairy cows fed a high protein diet (Jordan and Swanson, 1979; Williams et al., 1987). In a review of 24 studies, Hartog and van Kempen (1980) reported that a high energy intake during pig rearing generally increased embryonic mortality. In addition, although nutritional flushing of gilts for 5 days before insemination increased ovulation rate, it appeared to have no effect on the number of embryos remaining viable at day 25 of gestation (Emerson and Henricks, 1977). Although the mechanism by which high energy intake affects embryonic survival is unknown, it has been suggested that follicular and plasma steroid concentrations may play important roles (Matamorous et al., 1990; Jindal et al., 1997). Gilts fed a high energy diet do not show the typical changes in follicular steroid content during the oestrous cycle that are observed in feed-restricted gilts (Matamorous et al., 1990). This difference in follicular steroid content may affect the viability of the ovum, as suggested by Frachimont et al. (1989) in a study in which follicular fluid steroid content was correlated with the ability of human oocytes to be fertilized during in vitro fertilization. Furthermore, the addition of exogenous progesterone after the onset of oestrus increased embryonic survival in gilts with no feed restriction, indicating a role for periovulatory plasma progesterone in mediating nutrition-induced embryonic viability (Jindal et al., 1997).
The results of the present study are not conclusive regarding the effects of nutrition on in vitro embryo viability. Depending on initial cell stage and developmental endpoint, embryos from gilts inseminated at third oestrus and fed ad libitum demonstrated either increased or decreased development. Further studies are necessary to clarify the effects of nutrition on embryo viability.

Comparison of $1 \mathrm{~A}$ and $3 \mathrm{~A}$ treatments revealed significant differences in the distribution of embryonic stages at collection. A greater number of one- to two-cell embryos were collected from gilts inseminated at first oestrus and fed ad libitum, whereas gilts inseminated at third oestrus and fed ad libitum produced significantly more embryos in the one- to eight-cell category. Further investigation is required to determine whether embryos from developmentally heterogeneous flushes are at greater risk of mortality.

Although no oestrus-related effect on embryo recovery at the two- to four-cell stage was observed, data from the present study indicate that two- to four-cell embryos from gilts inseminated at first oestrus and fed ad libitum are less likely to survive to the morula stage than embryos from gilts inseminated at third oestrus and fed ad libitum. Furthermore, $1 \mathrm{~A}$ embryos collected at the two- to four-cell stage were much less likely to become expanded blastocysts than were embryos at the same stage from the $3 \mathrm{~A}$ treatment group.

Since nutrition is not a factor when comparing treatments 


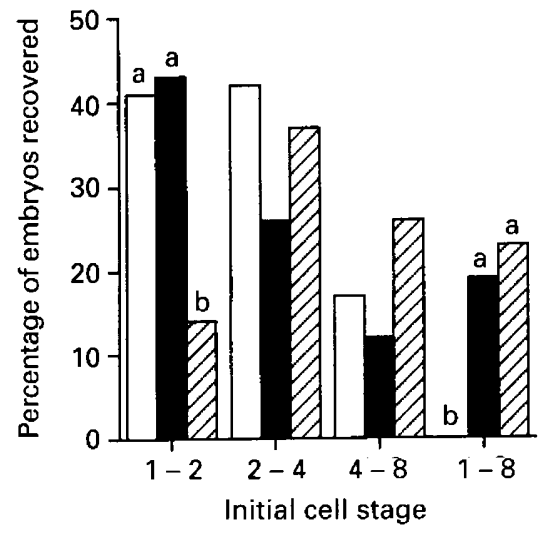

Fig. 1. Percentage of pig embryos at various cell stages at collection. Animals were inseminated at first oestrus and fed ad libitum $(\square$, group 1A); were inseminated at third oestrus and fed a restricted diet $(\boldsymbol{L}$, group 3R); or were inseminated at third oestrus and fed ad libitum $(\square$, group $3 A$ ). Initial cell stage 1-8 represents flushes that contained embryos at three or more cell stages. Values within an initial cell stage with different superscripts are significantly different $(P<0.05)$.

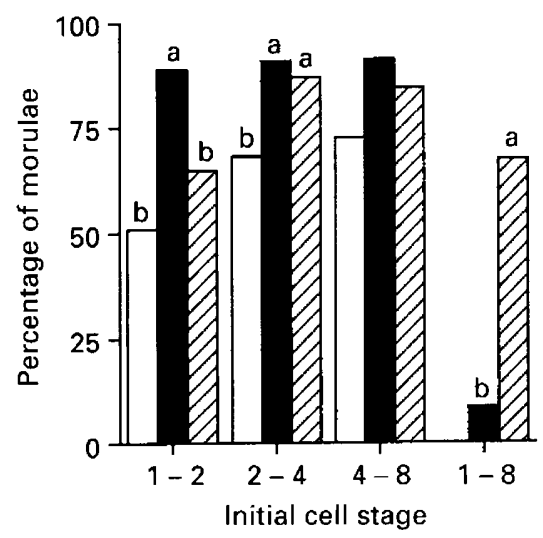

Fig. 2. Development of pig embryos to the compacted morula stage. Animals were inseminated at first oestrus and fed ad libitum $(\square$, group 1A); were inseminated at third oestrus and fed a restricted diet $(\square$, group 3R); or were inseminated at third oestrus and fed ad libitum ( $\square$, group $3 A$ ). Initial cell stage $1-8$ represents flushes that contained embryos at three or more cell stages. Values within an initial cell stage with different superscripts are significantly different $(P<0.05)$.

$1 \mathrm{~A}$ and $3 \mathrm{~A}$, there must be a factor inherent in the production of oocytes or early embryos at first oestrus that affects viability. Several studies have implicated plasma steroid concentration in embryo survival (Anderson, 1978; Pope and First, 1985; Dziuk, 1987; Blair et al., 1994). Embryonic growth is asynchronous in pig litters (Anderson, 1978), and some mortality may be attributed to oestrogen secretion by developmentally advanced embryos (Pope and First, 1985; Dziuk, 1987). Finally, although it has been demonstrated that gilts at first oestrus have lower concentrations of follicular steroids than do gilts at second or later oestrus (Smith $e$ t al., 1992), the significance of this differential steroid concentration remains unclear.

In conclusion, the results from the present study

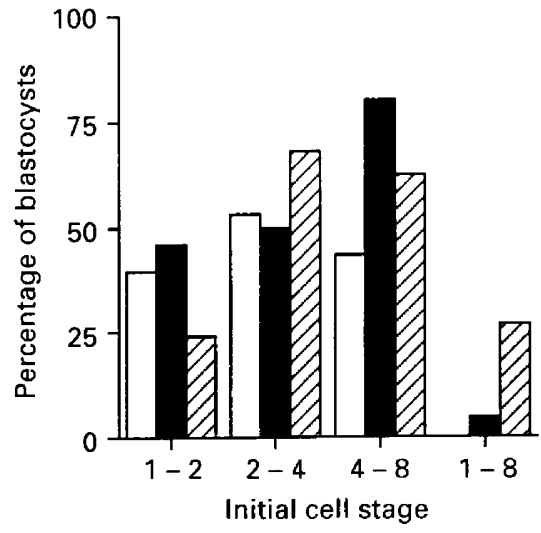

Fig. 3. Development of pig embryos to the blastocyst stage. Animals were inseminated at first oestrus and fed ad libitum ( $\square$, group 1A); were inseminated at third oestrus and fed a restricted diet $(\boldsymbol{\square}$, group $3 R$ ); or were inseminated at third oestrus and fed ad libitum ( $\square$, group 3A). Initial cell stage 1-8 represents flushes that contained embryos at three or more cell stages.

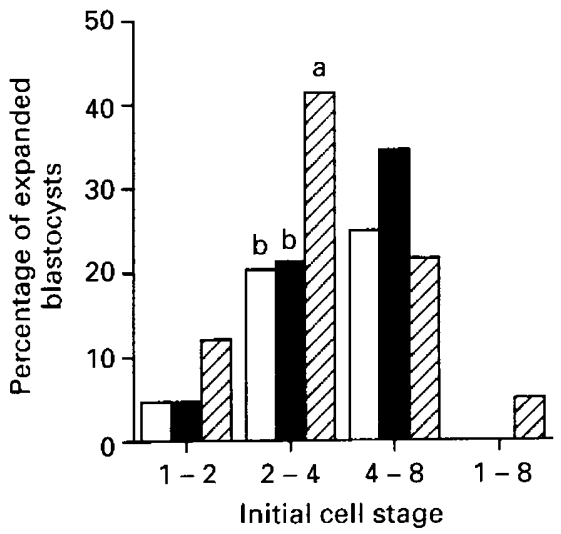

Fig. 4. Development of pig embryos to the expanded blastocyst stage. Animals were inseminated at first oestrus and fed ad libitum $(\square$, group 1A); were inseminated at third oestrus and fed a restricted diet $(\square$, group 3R); or were inseminated at third oestrus and fed ad libitum $(\square$, group $3 A)$. Initial cell stage $1-8$ represents flushes that contained embryos at three or more cell stages. Values within an initial cell stage with different superscripts differ $(P<0.05)$.

demonstrate that inseminating gilts at first oestrus results in decreased in vitro embryo development compared with insemination at a later oestrus. Although this effect is not removed by changing the nutrition of the gilts, ad libitum feeding may have an effect on in vitro embryo viability and may account for some of the reported difference in embryo survival between gilts inseminated at first and third oestrus. By clarifying the relationship between nutrition and the number of oestrous cycles, it may be possible to achieve a better understanding of the origins and mechanisms of embryonic mortality.

This research was supported by a grant from the Illinois Pork Producers Association. 


\section{References}

Anderson LL (1978) Growth, protein content and distribution of early pig embryos Anatomical Record 190 143-153

Andersson AM and Einarsson S (1980) Studies in the estrus and ovarian activity during five successive estrous cycles in gilts Acta Veterinaria Scandinavica 21 677-688

Antczak M and Van Blerkom J (1997) Oocyte influences on early development: the regulatory proteins leptin and STAT3 are polarized in mouse and human oocytes and differentially distributed within the cells of the preimplantation stage embryo Molecular Human Reproduction 3 1067-1086

Archibong AE, England DC and Stormshak F (1987) Factors contributing to early embryonic development in gilts bred at first estrus journal of Animal Science 64 474-478

Archibong AE, Maurer RR, Engalnd DC and Stromshak F (1992) Influence of sexual maturity of donor on in vivo survival of transferred porcine embryos Biology of Reproduction 47 1026-1030

Barash IA, Cheung CC, Weigle DS, Ren H, Kabigting EB, Kuijper JL, Clifton DK and Steiner RA (1996) Leptin is a metabolic signal to the reproductive system Endocrinology 137 3144-3147

Blair RM, Coughlin CM, Minton JE and Davis DL (1994) Peri-oestrous hormone profiles, embryonic development in gilts and primiparous sows journal of Reproduction and Fertility 101 167-173

Bryan KA and Hagen DR (1991) Effects of nutrient intake and sexual age of the dam at mating on fetal development in swine Growth, Development and Aging 55 27-33

Dziuk PJ (1987) Embryonic Loss in the Pig: An Enigma Manipulating Pig Production p. 28 Eds APSA Committee. Australasian Pig Science Association, Werribee

Emerson DD and Hendricks DM (1977) The effects of low levels of PMSG and flush feeding upon embryonic survival in gilts Theriogenology 8 281-291

Franchimont P, Hazee-Hagelstein A, Haazout A, Frydman R, Schatz B and Demerle F (1989) Correlation between follicular fluid content and the results of in vitro fertilization and embryo transfer 1 . Sex steroids Fertility and Sterility 53 1006-1011

Hartog LA and van Kempen GJM (1980) Relation between nutrition and fertility in pigs Netherlands journal of Agricultural Science 28 211- 227

Hinkle DE, Wiersma W and Jurs SG (1988) Applied Statistics for the Behavioral Sciences 2nd Edn. Houghton Mifflin Company, Boston

Jindal R, Cosgrove JR and Foxcroft GR (1997) Progesterone mediates nutritionally induced effects on embryonic survival in gilts Joumal of Animal Science 75 1063-1070

Jordan ER and Swanson LV (1979) Effect of crude protein on reproductive efficiency, serum total protein, and albumin in the high-producing dairy cow Journal of Dairy Science $6258-62$

Kirkwood RN and Thacker PA (1988) Nutritional factors affecting embryo survival in pigs (Results and Speculations) Pig News Information 91-15

Koenig JLF and Stormshak F (1993) Cytogenetic evaluation of ova from pubertal and third estrous gilts Biology of Reproduction 49 1158-1162

MacPherson RM, Hovell FDD and Jones AS (1977) Performance of sows first mated at puberty or second or third estrus, and carcass assessment of oncebred gilts Animal Production 24 333-342

Matamorous IA, Cox NM and Moore AB (1990) Exogenous insulin and additional energy affect follicular distribution, follicular steroid concentrations, granulosa cell human chorionic binding in swine Biology of Reproduction $431-7$

Menino AR, Jr, Archibong AE, Li JR, Stormshak F and England DC (1989) Comparison of in vitro development of embryos collected from the same gilts at first and third estrus Journal of Animal Science 67 1387-1393

Murray FA and Grifo AP, Jr (1976) Development of capacity to secrete progesterone-induced protein by the porcine uterus Biology of Reproduction $15620-625$

Paterson AM and Lindsay DR (1980) Induction of puberty in gilts Animal Production 31 291-298

Pope WF and First NL (1985) Factors affecting the survival of embryos Theriogenology 23 91-105

Robertson GL, Casida LE, Grummer RH and Chapman AB (1951) Some feeding and management factors affecting age at puberty and related phenomena in Chester White and Poland China gilts Journal of Animal Science 10 841-866

Smith GD, Menino AR, Jr, Rowe KE and Stormshak F (1992) Steroids and plasminogen activator concentrations in follicular fluid of gilts at first and third estrus Journal of Animal Science 67 1387-1393

Steel RGD and Torrie JH (1980) Principles and Procedures of Statistics: A Biometrical Approach 2nd Edn. McGraw-Hill Book Co., New York

Warnick AC, Wiggins EL, Casida LE, Grummer RH and Chapman AB (1951) Variation in puberty phenomena in inbred gilts Journal of Animal Science $\mathbf{1 0}$ 479-493

Weigle DS, Bukowski TR, Foster DC, Holderman S, Kramer JM, Lasser G, Lofton-Day CE, Prunkard DE, Raymond C and Kuijper JL (1995) Recombinant ob protein reduces feeding and body weight in the $\mathrm{ob} / \mathrm{ob}$ mouse Journal of Clinical Investigations 96 2065-2070

Whaley SL, Hedgpeth VS and Britt JH (1997) Evidence that injection of vitamin A before mating may improve embryo survival in gilts fed normal or high energy diets Journal of Animal Science 75 1071-1077

Whitten WK and Biggers JD (1968) Complete development in vitro of the preimplantation stages of the mouse in a simple chemically defined medium Journal of Reproduction and Fertility 17 399-401

Williams JS, Gardiner CS, Schuller LS, Swanson LV and Menino AR, Jr (1987) Evaluation of uterine flushings collected from dairy cows fed two levels of crude protein Proceedings of the Western Section of the American Society of Animal Scientists 38 253-258

Wilmut I and Sales DI (1981) Effect of an asynchronous environment on embryonic development in sheep joumal of Reproduction and Fertility $\mathbf{6 1}$ 179-184

Young LG and King GJ (1981) Reproductive performance of gilts bred on first versus third estrus Journal of Animal Science 53 19-25

Zak LJ, Xu X, Hardin RT and Foxcroft GR (1997) Impact of different patterns of feed intake during lactation in the primiparous sow on follicular development and oocyte maturation Journal of Reproduction and Fertility 110 99-106 